\title{
ASSESSMENT OF DIVERSITY OF POLISH VOIVODSHIPS BY LEVEL OF GAS PIPELINE INFRASTRUCTURE DEVELOPMENT USING MULTIDIMENSIONAL COMPARATIVE ANALYSIS
}

\begin{abstract}
In the paper differentiation of gas pipeline infrastructure development in the Polish voivodships was presented. To illustrate this diversity the method of cluster analysis is used, obtained on the basis of statistical data collected by the Central Statistical Office (CSO). In order to conduct a preliminary review procedure for classification of individual provinces in relation to the assessment of the development of gas pipeline infrastructure linear classification was used, involved determining synthetic measure, which is the average of the variable components, through which voivodships were ordered. In order to estimate the distance between the clusters the variance analysis was used with the implementation of the Ward method. The analysis was performed on the basis of the following indicators: average increase in length of the gas network (an average for the total voivodoship $164.2 \mathrm{~km}$ ), growth of the gas network in comparison to the first year of observation (123\%), number of gas connections per $1 \mathrm{~km}$ of gas pipe $\left(18.87 \mathrm{no}^{-\mathrm{km}^{-1}}\right)$, the length of the network per unit area $\left(5.37 \mathrm{~m} \cdot \mathrm{ha}^{-1}\right)$, intensity of network loading $\left(84.15 \mathrm{~m}^{3} \cdot \mathrm{d}^{-1} \cdot \mathrm{km}^{-1}\right)$, inhabitants having access to the gas system in \% of total population $(51.33 \%)$. In the analysis five clusters were grouped. Critical value was determined and segregation of individual clusters was made, taking into account the dominant parameters.
\end{abstract}

Keywords: cluster analysis, indicators of equipment in gas networks, multidimensional comparative analysis

\section{Introduction}

Environmental policy is one of the most important priorities of the European Union, natural gas is the most environmentally friendly fossil fuel, which gives it more and more important place in EU fuel policy $[1,2,10]$. The EU has launched a number of systems of financial assistance in order to implement projects promoting the use of natural gas. The main stimulus of such actions is the ecology and an economic factor has also the considerable influence [5-7, 14].

\footnotetext{
${ }^{1}$ Autor do korespondencji/corresponding author: Marek Urbanik, Politechnika Rzeszowska, al. Powstańców Warszawy 6, 35-959 Rzeszów, tel. 17 86514408, d314@ stud.prz.edu.pl
} 
Due to the importance of the discussed problems an important issue seems to be the analysis of the diversity of Polish voivodships in the context of the level of development of gas pipeline infrastructure in the Polish voivodships in the years 2005-2014.

In order to know this diversity the Cluster Analysis method was proposed.

The analysis applies to the following elements of infrastructure: length of the gas network, the number of connections of gas pipelines leading to residential buildings, the number of connections per $1 \mathrm{~km}$ of the gas network, the intensity of the workload, indicators of the equipment degree of settlement units in gas networks, comparison of the development of gas pipeline infrastructure in individual provinces.

The primary source of data for this work was the Central Statistical Office [4].

\section{Ranking of voivodships in terms of level of gas pipeline infrastructure development}

The method of multidimensional analysis can be a helpful tool in ranking and assessment of the level of gas pipeline infrastructure development. In order to perform a procedure for the classification of individual Polish provinces in terms of the gas infrastructure development linear classification determining synthetic measure, which is the average of the variable components, was used. Then Polish voivodoships were ordered and before the analysis the unitarisation of variables with different titers was made.

Profiles of selected three provinces having the best (a) and the worst place (b) in classification of voivodships as a result of unitarisation are shown in Figure 1, where: $a$ - the average increase in length of the gas network, $b$ - growth of the gas network in comparison to the first year of observation [\%], $c$ - number of gas connections per $1 \mathrm{~km}$ of gas pipe, $\left[\mathrm{no}^{\circ} \mathrm{km}^{-1}\right], d$ - the length of the network per unit area $\left[\mathrm{m}^{2} \mathrm{ha}^{-1}\right], e$ - intensity of network loading $\left[\mathrm{m}^{3} \cdot \mathrm{d}^{-1} \cdot \mathrm{km}^{-1}\right], f$ - inhabitants having access to the gas system in \% of total population [\%].

For every voivodships the minimum and maximum synthetic indicator had an considerable influence. In case of Masovian Province- paramter $\mathrm{c}$ and in case of Pomeranian - parametr $b$ caused that those Provinces took the highest place in rankings, in contrast to parameters a, $\mathrm{d}$ and $\mathrm{f}$, which caused that Podlasie took the last worst place in the level of the development of gas infrastructure.

The analysis of the level of diversification of gas infrastructure in all voivodoships was performed using tools of Multidimensional Comparative Analysis (MCA). In this method similar observations are grouped in the so-called clusters.

While creating groups, it should be remembered, that they should considerably vary between themselves. Clusters created in this way are then organized in clear structures, based on the analysis of the similarities in given area.

These similarities may be suitable indicators specific for this group, similarity or the distance, the result is a method of presenting the objects, their properties showing both shared and distinct characteristics [11]. 
a)

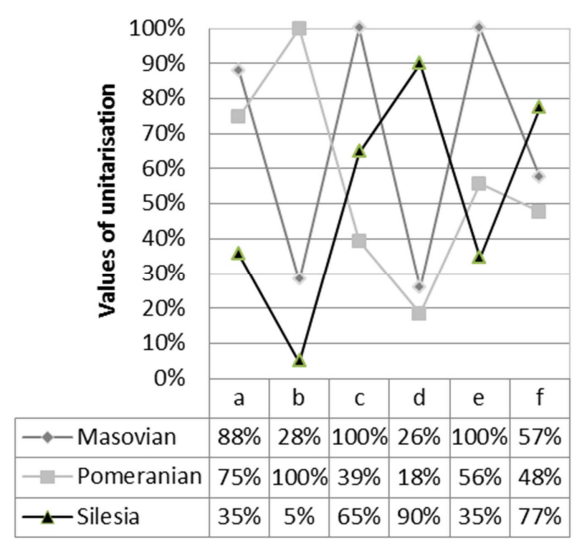

b)

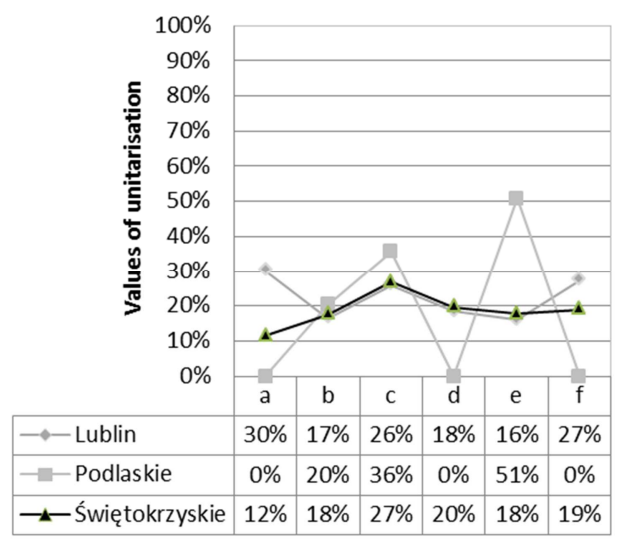

Fig. 1. Profiles of individual provinces as a result of unitarisation

Rys. 1. Profile poszczególnych województw powstałe w wyniku unitaryzacji

In order to estimate the distance between the clusters can be used analysis of variance. This approach is illustrated in the method of Ward, which is to minimize the sum of squared deviations of any two clusters that can be formed at any stage [13]. Although this procedure results in the formation of aggregates of very short distance, due to its effectiveness is often used, the degree of development of infrastructure using comparative analysis methods were used in works $[3,12,15]$.

To determine the assessment of the diversity of gas network uses development Euclidean distance matrix was used according to the formula [9]:

$$
d\left(x_{i}, x_{k}\right)=\sqrt{\sum_{j=1}^{m}\left(x_{i j}-x_{k j}\right)^{2}}
$$

where $x_{i j}$ - value of $j^{\text {th }}$ variable for $i^{\text {th }}$ object, $x_{k j}$ - value of $j^{\text {th }}$ variable for $k^{\text {th }}$ object and $d\left(x_{i}, x_{k}\right)$ - the distance between the $i^{\text {th }}$ and $k^{\text {th }}$ object.

Then the method of clusters agglomeration was applied, involving the determination of a hierarchical tree called dendrogram, which was made using the Z. Hellwig method [8]. It allows to estimate the distance between points belonging to two different subsets.

In Table 1 the hierarchy of individual clusters including individual voivodships was presented: Lower Silesian (O_1), Kuyavian Pomeranian (O_2), Lublin (O_3), Lubusz (O_4), Łódź (O_5), Lesser Poland (O_6), Masovian (O_7), Opole (O_8), Subcarpathian (O_9), Podlaskie (O_10), Pomeranian (O_11), Silesia (O_12), Świętokrzyskie (O_13), Warmian Masovian (O_14), Greater Poland (O_15), West Pomeranian (O_16). 
Table 1. The course of clusters agglomeration

Tabela 1. Przebieg aglomeracji skupień

\begin{tabular}{|c|c|c|c|c|c|c|c|c|c|c|c|c|c|c|c|c|}
\hline Euclidean & & & & & & he $c$ & urse & f clu & ers a & lome & ratior & & & & & \\
\hline 0.14 & $\mathrm{O}_{2}$ & $\mathrm{O}_{5}$ & & & & & & & & & & & & & & \\
\hline 0.17 & $\mathrm{O}_{-}$ & $\begin{array}{l}\mathrm{O}_{-} \\
14\end{array}$ & & & & & & & & & & & & & & \\
\hline 0.20 & $\mathrm{O}_{-}$ & $\begin{array}{l}\mathrm{O}_{-} \\
13\end{array}$ & & & & & & & & & & & & & & \\
\hline 0.32 & $\mathrm{O}_{-}$ & $\begin{array}{l}\mathrm{O}_{-} \\
12\end{array}$ & & & & & & & & & & & & & & \\
\hline 0.33 & $\mathrm{O}_{-}$ & $\begin{array}{l}\mathrm{O}_{-} \\
16\end{array}$ & & & & & & & & & & & & & & \\
\hline 0.46 & $\mathrm{O}_{-}$ & $\begin{array}{l}\mathrm{O}_{-} \\
14\end{array}$ & $\mathrm{O}_{-}$ & & & & & & & & & & & & & \\
\hline 0.50 & $\mathrm{O}_{-}$ & $\mathrm{O}_{-}$ & $\mathrm{O}_{-}$ & & & & & & & & & & & & & \\
\hline 0.50 & $\mathrm{O}_{6}$ & $\begin{array}{l}\mathrm{O}_{-} \\
12\end{array}$ & $\mathrm{O}_{-}$ & & & & & & & & & & & & & \\
\hline 0.57 & $\mathrm{O}_{-}$ & $\begin{array}{l}O_{-} \\
13\end{array}$ & $\mathrm{O}_{-}$ & $\mathrm{O}_{-}$ & $\mathrm{O}_{-}$ & & & & & & & & & & & \\
\hline 0.70 & $\begin{array}{l}\mathrm{O}_{-} \\
11\end{array}$ & $\begin{array}{l}\mathrm{O}_{-} \\
15\end{array}$ & & & & & & & & & & & & & & \\
\hline 0.73 & $\mathrm{O}_{-}$ & $\mathrm{O}_{4}$ & $\mathrm{O}_{-}$ & $\mathrm{O}_{2}$ & $\mathrm{O}_{5}$ & & & & & & & & & & & \\
\hline 1.12 & $\mathrm{O}_{-}$ & $\begin{array}{l}\mathrm{O}_{-} \\
11\end{array}$ & $\begin{array}{l}\mathrm{O}_{-} \\
15\end{array}$ & & & & & & & & & & & & & \\
\hline 1.42 & $\begin{array}{c}\mathrm{O}_{-} \\
1\end{array}$ & $\mathrm{O}_{4}$ & $\begin{array}{l}\mathrm{O}_{-} \\
16\end{array}$ & $\mathrm{O}_{2}$ & $\mathrm{O}_{5}$ & $\mathrm{O}_{3}$ & $\mathrm{O}_{-}$ & $\mathrm{O}_{-}$ & $\mathrm{O}_{-}$ & $\mathrm{O}_{1}$ & & & & & & \\
\hline 2.16 & $\begin{array}{c}\mathrm{O}_{-} \\
1\end{array}$ & $\mathrm{O}_{-}$ & $\begin{array}{l}\mathrm{O}_{-} \\
16\end{array}$ & $\mathrm{O}_{-}$ & $\mathrm{O}_{5}$ & $\begin{array}{c}\mathrm{O}_{-} \\
3\end{array}$ & $\begin{array}{l}\mathrm{O}_{-} \\
13\end{array}$ & $\begin{array}{l}\mathrm{O}_{-} \\
8\end{array}$ & $\begin{array}{l}\mathrm{O}_{-} \\
14\end{array}$ & $\begin{array}{l}\mathrm{O}_{-} \\
10\end{array}$ & $\begin{array}{c}O_{-} \\
7\end{array}$ & $\begin{array}{l}\mathrm{O}_{-} \\
11\end{array}$ & $\begin{array}{l}\mathrm{O}_{-} \\
15\end{array}$ & & & \\
\hline 3.29 & $\mathrm{O}_{-}$ & $\mathrm{O}_{-}$ & $\begin{array}{l}\mathrm{O}_{-} \\
16\end{array}$ & $\mathrm{O}_{-}$ & $\mathrm{O}_{5}$ & $\mathrm{O}_{3}$ & $\begin{array}{l}\mathrm{O}_{-} \\
13\end{array}$ & $\mathrm{O}_{8}$ & $\begin{array}{l}\mathrm{O}_{-} \\
14\end{array}$ & $\begin{array}{l}\mathrm{O}_{-} \\
10\end{array}$ & $\mathrm{O}_{-}$ & $\begin{array}{l}\mathrm{O}_{-} \\
11\end{array}$ & $\mathrm{O}_{1}$ & $\mathrm{O}_{-}$ & $\mathrm{O}_{-}$ & $\mathrm{O}_{-}$ \\
\hline
\end{tabular}

To determine the individual clusters and corresponding to them voivodships the critical value $W_{k}=0.77$ was used, which allowed to achieve the following five clusters:

$-1^{\text {st }}$ cluster: Subcarpathian, Silesia, Lesser Poland,

$-2^{\text {nd }}$ cluster: Greater Poland, Pomeranian,

$-3^{\text {rd }}$ cluster: Masovian,

$-4^{\text {th }}$ cluster: Podlaskie, Warmian Masovian, Opole, Świętokrzyskie, Lublin,

$-5^{\text {th }}$ cluster: Łódź, Kuyavian Pomeranian, West Pomeranian, Lubusz, Lower Silesian.

The next step was to analyse the individual clusters, which can be performed by calculating the ratio of the arithmetic average of each cluster $X_{i}$ to average group $X$, as shown graphically in Figure 2. Calculated ratio $X_{i} / X$ higher then one indicates a domination of a specific parameter in a given cluster [9]. 

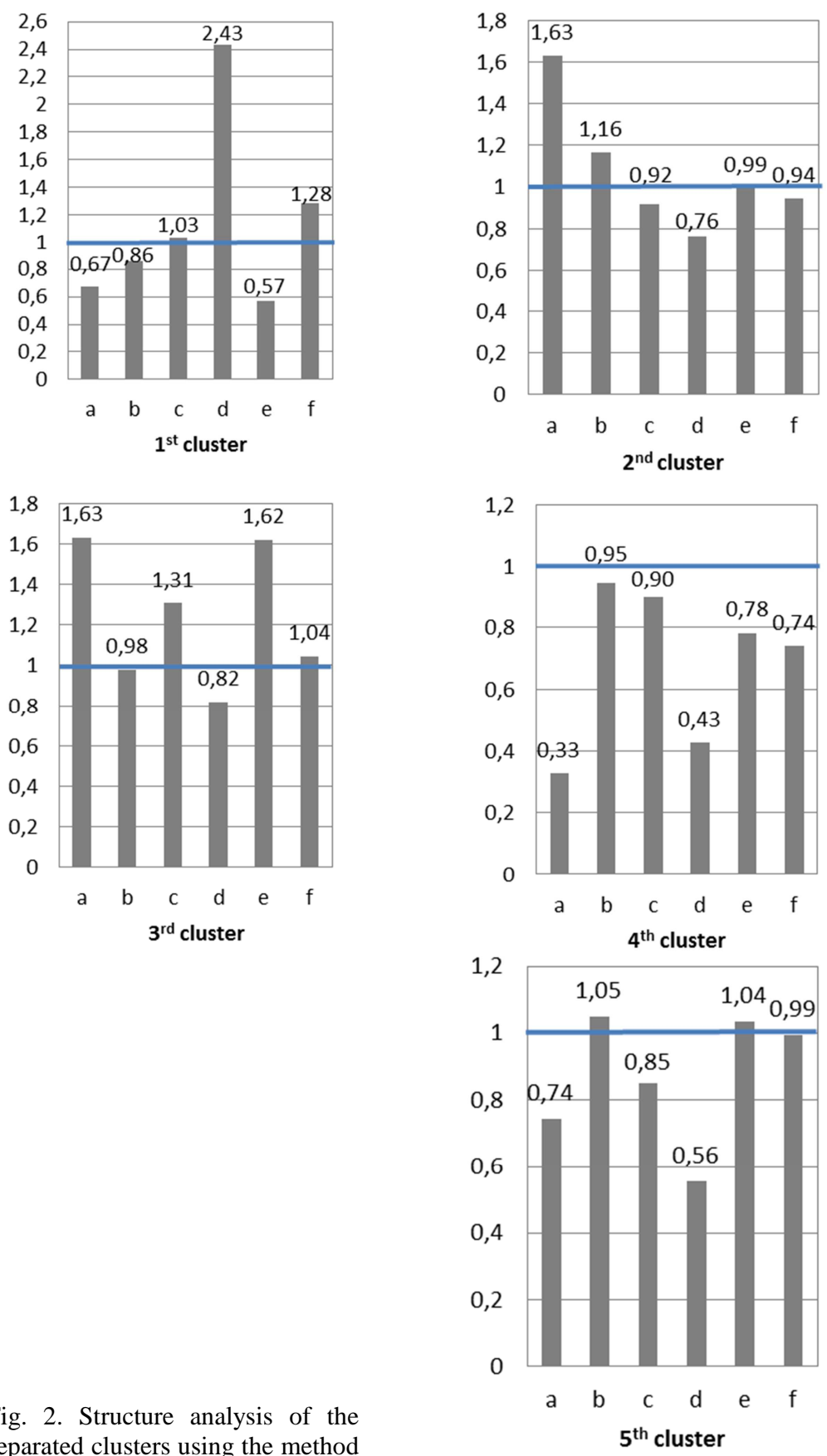

Fig. 2. Structure analysis of the separated clusters using the method of arithmetic averages

Rys. 2. Analiza struktury wydzielonych skupień za pomocą metody średnich arytmetycznych 
The dominant role in the process of grouping played a characteristic that describes the average increase in length of the gas supply network (cluster: $2^{\text {nd }}$ and $3^{\text {rd }}$ ), growth of the gas network in comparison to the first year of observation (cluster: $2^{\text {nd }}$ and ${ }^{5 \text { th }}$ ), number of gas connections per $1 \mathrm{~km}$ of gaspipe (cluster: $1^{\text {st }}$ and $3^{\text {rd }}$ ). The length of the network per unit area played an important role only in the process of grouping the first cluster, while the intensity of network loading in creating clusters $3^{\text {rd }}$ and $5^{\text {th }}$, characteristics describing inhabitants having access to the gas system dominated in clusters $1^{\text {st }}$ and $3^{\text {rd }}$.

\section{Conclusion}

The proposed analysis of the differentiation in the development of gas pipeline infrastructure using the tools of multidimensional comparative analysis allowed to show the diversity of characteristics indicating which region is characterized by a high level of gas pipeline infrastructure development .

The structure of separated clusters, taking into account the characteristics of dominant is as follows:

- about creation of $1^{\text {st }}$ cluster high length of the network per unit area $\left(13.07 \mathrm{~m} \cdot \mathrm{ha}^{-1}\right)$ decided, with, at the same time, a very low rate, among all clusters, concerning intensity of network loading $48 \mathrm{~m}^{3} \cdot \mathrm{d}^{-1} \cdot \mathrm{km}^{-1}$,

- high growth of the gas network decide about forming $2^{\text {nd }}$ cluster of about $143 \%$,

- the most differentiating province is the single element cluster ( $3^{\text {rd }}$ cluster), which is the most developed in terms of economic, resulting in the development of gas infrastructure, which affects the highest, in comparison to other of voivodships, index of the average increase in length of the gas network, number of gas connections per $1 \mathrm{~km}$ of gas pipe $\left(24.6 \mathrm{no} \cdot \mathrm{km}^{-1}\right)$ and the highest intensity of network loading amounting $136.33 \mathrm{~m}^{3} \cdot \mathrm{d}^{-1} \cdot \mathrm{km}^{-1}$, which undoubtedly is associated with a high population density,

- individual indicators are at the average level in the $4^{\text {th }}$ cluster, except for the rate of growth of the gas network, which is close to one, the average value for the voivodships in this concentration is $116 \%$,

- key indicators describing the development of gas infrastructure of voivodships forming the $5^{\text {th }}$ cluster are: growth of the gas network (129\%), intensity of network loading $\left(87.18 \mathrm{~m}^{3} \cdot \mathrm{d}^{-1} \cdot \mathrm{km}^{-1}\right)$, inhabitants having access to the gas system $(51 \%)$.

Comparison criterion may be any of the parameters characterizing the development of infrastructure. 


\section{Literature}

[1] Dieckhoener C., Lochner S., Lindenberger D.: Simulating the Effects of European Natural Gas Infrastructure Developments, Oil Gas-European Magazine, 36(4) 2010, pp. 174-185.

[2] Dilaver O., Dilaver Z., Hunt L.C.: What drives natural gas consumption in Europe? Analysis and projections. Journal of Natural Gas Science and Engineering, (19)2014, 125-36.

[3] Franco A., Fantozzi F. Analysis and clustering of natural gas consumption data for thermal energy use forecasting, Journal of Physics Conference Series, 655, 2015, 012020, DOI: 10.1088/1742-6596/655/1/012020.

[4] Główny Urząd Statystyczny, Ochrona środowiska, Roczniki statystyczne za lata 2005-2014.

[5] Gorczyca M. Statystyczne wskaźniki energetyczne 27 krajów wchodzących w skład Unii Europejskiej (UE), Energetyka, Nr 5/2013.

[6] Gorczyca, M. Stan rozwoju gazownictwa - statystyczne spektrum, Gaz, Woda i Technika Sanitarna, Nr 5/2010.

[7] Huang Z., Yu H., Peng Z., Zhao M., 2015. Methods and tools for community energy planning: A review. Renew. and Sust. Energy Reviews, (42)2015, 1335-1348.

[8] Hellwig Z.: Zarys ekonometrii, PWE, Warszawa 1973.

[9] Marek T.: Analiza skupień w badaniach empirycznych. PWN, Warszawa 1989.

[10] Ozturk I., Al-Mulali U.: Natural gas consumption and economic growth nexus: Panel data analysis for GCC countries, Renewable \& Sustainable Energy Reviews, (51)2015, pp. 998-1003.

[11] Panek T., Statystyczne metody wielowymiarowej analizy porównawczej. SGH, Warszawa 2009.

[12] Pietrucha-Urbanik K, Tchórzewska-Cieślak B. Water Supply System operation regarding consumer safety using Kohonen neural network; in: Safety, Reliability and Risk Analysis: Beyond the Horizon - Steenbergen et al. (Eds), Taylor \& Francis Group, London 2014: 1115-1120.

[13] Ward J. H.: Hierarchical grouping to optimize an objective function, Journal of the American Statistical Association, 58(3)1963, pp. 236-244.

[14] Urbanik M., Tchórzewska-Cieślak B.: Ecological aspects of the natural gas use, Czasopismo Inżynierii Lądowej, Środowiska i Architektury JCEEA, t. XXXII, z. 62 (1/15), s. 409-417. DOI: 10.7862/rb.2015.29.

[15] Urbanik M., Tchórzewska-Cieślak B.: Podstawy analizy niezawodności funkcjonowania instalacji wykorzystujących gaz ziemny, Czasopismo Inżynierii Lądowej, Środowiska i Architektury JCEEA, t. XXXII, z. 62 (1/15), s. 419-431. DOI: 10.7862/rb.2015.30. 


\section{OCENA ZRÓŻNICOWANIA WOJEWÓDZTW POLSKI ZE WZGLĘDU NA POZIOM ROZWOJU INFRASTRUKTURY GAZOCIACGOWEJ Z ZASTOSOWANIEM WIELOWYMIAROWEJ ANALIZY PORÓWNAWCZEJ}

\section{Streszczenie}

W pracy przedstawiono zróżnicowanie poziomu infrastruktury gazociągowej w województwach polski. Dla zobrazowania tego zróżnicowania zastosowano metodę Analizy Skupień, sporządzoną na podstawie analizy danych statystycznych zebranych przez Główny Urząd Statystyczny (GUS). W celu przeprowadzenia wstępnej procedury klasyfikacji poszczególnych województw względem oceny rozwoju infrastruktury gazociągowej zastosowano klasyfikację liniową polegającą na wyznaczeniu miernika syntetycznego, będącego średnią wartości zmiennych składowych, według którego uporządkowano województwa. W celu oszacowania odległości między skupieniami wykorzystano analizę wariancji, z zastosowaniem metody Warda. Analizę przeprowadzono na podstawie następujących wskaźników: średni wzrost długości sieci gazociągowej (średnio dla wszystkich województw $164.2 \mathrm{~km}$ ), wzrost sieci gazociagowej w porównaniu do pierwszego roku obserwacji (123\%), liczba przyłączy na $1 \mathrm{~km}$ gazociągu $\left(18.87\right.$ no $\left.\mathrm{km}^{-1}\right)$, długość sieci przypadająca na jednostkę powierzchni $\left(5.37 \mathrm{~m} \cdot \mathrm{ha}^{-1}\right)$, intensywność obciążenia sieci gazociągowej $\left(84.15 \mathrm{~m}^{3} \cdot \mathrm{d}^{-1} \cdot \mathrm{km}^{-1}\right)$, mieszkańcy mający dostęp do systemu gazociągowego w \% ludności ogółem $(51.33 \%)$. W wyniku analizy wyodrębniono pięć skupien. Wyznaczono wartość krytyczną i dokonano segregacji poszczególnych skupień z uwzględnieniem dominujących parametrów.

Słowa kluczowe: analiza skupień, wskaźniki wyposażenia w sieciach gazowych, wielowymiarowa analiza porównawcza

Przestano do redakcji: 29.01.2016 r.

Przyjęto do druku: 1.06.2016 r.

DOI: $10.7862 / \mathrm{rb} .2016 .134$ 